\title{
PLACE OF METACOGNITION IN THE TURKISH NATIONAL CURRICULUM OF READING
}

\author{
RESEARCH ARTICLE
}

\section{Nesrin ÖZTüRK'}

1 Dr. Öğ. Üyesi, İzmir Demokrasi Üniversitesi, Eğitim Bilimleri Bölümü,ozturknesrin@gmail.com, ORCID: 0000-0002-7334-8476.

\begin{abstract}
:
Metacognition research has provided evidence for its beneficiary impacts on vocabulary, reading awareness, skills, comprehension, performance, and responsibility for learning. However, the realties between research and mainstream classrooms are not similar; students in mainstream classrooms may suffer from deficiency of metacognitive competencies for various reasons. The curriculum might be a potential reason for this problem. Therefore, via document analysis and thematic deductive coding, the national curriculum of Turkish language, specifically reading standards, were analysed to identify the place and weight of metacognition in this specific context. The analysis revealed that reading standards recognize metacognition and might help students develop metacognitive competencies to a limited extend. In its current form, standards can develop students' metacognitive knowledge about text structures, genre, mechanics, and language use and they can also help students' practice few planning strategies, couple of fix-up and/or comprehension strategies, and comprehension evaluation. Metacognitive experiences may provide students with opportunities to supplement limited metacognitive knowledge, regulation of strategies, and doing self-assessment by reasoning and/or critical thinking. It is important to revise the standards to include metacognitive knowledge about reading, self, strategies, and task and to have students practice self-assessment of reading process, effectiveness of strategies, reading products, and task completion or goal-achievement. It is also important for teacher education programs to include at least, elective classes for teaching metacognition, therefore, such standards can be realized, effectively.
\end{abstract}

Keywords: metacognition, reading, elementary school, middle school, curriculum, reading standards 


\title{
ÜSTBILIŞIN ULUSAL OKUMA ÖĞRETIM PROGRAMINDAKI YERI
}

\begin{abstract}
Öz: Alan araştırmaları, üstbilişin kelime hazinesi, okuma bilinci, okuma becerileri, okuduğunu anlama, performans ve öğrenme sorumluluğu üzerinde olumlu etkileri olduğunu ortaya koymuştur. Fakat, araştırma ve normal sınıflardaki gerçekler benzer değildir; normal sınıflardaki öğrenciler, üstbilişsel yeterliliklere sahip olmayabilir ve uygulamadaki öğretim programları bu sorunun nedenlerinden biri olabilir. Bu bağlamda, İlkokul ve Ortaokul Türkçe Programı'nda üstbilişin yerini ve ağırlı̆̆ını belirlemek amacıyla, okuma kazanımları doküman analizi ve tümden gelimsel tematik kodlama yoluyla incelenmiştir. Bulgular, ulusal programdaki okuma kazanımlarının üstbilişi tanıdığını ve öğrencilerin üstbilişsel yeterliklerini sınırlı ölçüde geliştirmelerine yardımcı olabileceğini ortaya koymuştur. Bu kazanımlar, öğrencilerin metin yapısı, türü, mekanik ve dil kullanımı bağlamında üstbilişsel bilgileri geliştirebilir ve bu kazanımlar öğrencilerin sınırlı sayıda planlama, düzenleme ve okuma-anlama ile değerlendirme becerilerini kazanmalarına yardımcı olabilir. Kazanımlar bağlamında oluşturulabilecek üstbilişsel deneyimler, öğrencilere üstbilişsel bilgiyi geliştirme, stratejileri düzenlenme ve öz değerlendirme yapma fırsatları sağlayabilir. Okuma kazanımları, öğrencilerin okuma, okuyucu olarak birey, stratejiler ve okuma görevleri hakkında üstbilişsel bilgilerini geliştirecek ve okuma süreci, stratejilerin etkililiği, okuma ürünleri, görev veya hedeflerle ilgili öz değerlendirme yapmalarını sağlayacak şekilde revize edilmelidir. Ayrıca, kazanımların hayata geçirilmesini mümkün kılacak öğretmenler düşünüldüğünde, öğretmen eğitimi programlar1nın üstbiliş öğretimini hedef alan seçmeli derslere yer vermesi önemlidir.
\end{abstract}

Anahtar Kelimler: üstbiliş, okuma, ilkokul, ortaokul, öğretim programı, okuma kazanımları

\section{Introduction}

Metacognition pertains to higher-order thinking or thinking about cognitions (Flavell, 1979). As Veenman, Van Hout-Wolters, and Afflerbach (2006) emphasized, metacognition is 'a higher-order agent overlooking and governing the cognitive system, while simultaneously being part of it' (p.5). According to Flavell (1979), cognitions can be controlled through the actions and interactions of metacognitive knowledge, metacognitive strategies, and metacognitive experiences.

Metacognition is an effective tool for learning (Fisher, 2002; Kerndl \& Aberšek, 2012) and it is also an important predictor (Veenman, 2016; Wang et al., 1990) of various cognitive enterprises such as 'reading comprehension, writing, language acquisi- 
tion, attention, memory, problem-solving' (Flavell, 1979, p. 906). Via metacognition, individuals can perform such cognitions, strategically and efficiently (Gourgey, 1998). Therefore, it may be a major distinction between low and high achievers (Paris \& Jacobs, 1984; Pogrow, 2004).

Reading, one of the important cognitive acts both for schools and out of it, pertains to meaning-making. It is a complex and purposeful act of perceptual processes, cognitive skills, and metacognition (Book et al., 1985; Doğanay Bilgi \& Özmen, 2014; Myers $\&$ Paris, 1978). Cognitive strategies are used to comprehend and gain information from the text while metacognitive strategies are employed for the effectiveness of cognitive strategies (Gourgey, 1998, 2001). Research found that metacognition helps improve vocabulary, reading awareness, skills, comprehension, performance, and responsibility for learning (Boulware-Gooden et al., 2007; Curwen et al., 2010; Veenman et al., 2006).

\section{Problem and Purpose of Research}

Research demonstrated that metacognition may be successfully taught (Anastasiou \& Griva, 2009; Cross \& Paris, 1988; Ozturk, 2015; Pintrich, 2002; Schraw, 1998; Tanner, 2012; Zohar \& Ben David, 2009). However, extant studies have limited influence on mainstream classrooms (Carroll, 2008; Curwen et al., 2010; Van Keer \& Vanderlinde, 2010) and as Baker (2017) stated, the realities in research and mainstream classrooms are different. That is, while research classroom students might show excellent or at least, sufficient adequacy with metacognitive behaviors, classroom students might suffer from deficiency or have limited competencies with metacognition. Studies carried out in Turkey second this argument. Sevgi and Çağliköse (2020), for example, currently examined 624 6th grade students' metacognition by measuring it on a metacognition scale and reported its being on average. These findings were not different than the previous research. Altunkaya and Sülükçü (2018) who worked with 271 7th grade students also found that students' reading strategies and fix-up strategies were on average. Öksüz et al. (2015) employed a methodology which might reflect developmental trajectory of metacognition as they analyzed students' metacognitive competencies across secondary school. They similarly found that 5th, 6th, 7th, and 8th grade students had average metacognitive competencies and there were no statistical differences among any grade levels. Research methods which let in-depth analysis, on the other hand, reported more pessimistic findings. For example, Çetinkaya Edizer and Özbilgin (2019) examined 8th grade students metacognitive reading strategies via interview method and found that students in their study hardly used before, during, and after metacognitive reading strategies.

Students' realities in research and mainstream classrooms might be different due to factors, including teachers' awareness of metacognition. That is, instruction in schools may hardly include explicit metacognition instruction as teachers themselves might not develop and/or have an awareness of teaching metacognition. Studies done in 
Turkey provided evidence for this argument. For example, Erdağ 1 Toksun and Toprak (2019) studied with 183 in-service Turkish language teachers and examined their metacognition awareness. Using an inventory to identify awareness of reading strategies, the authors found that teachers' metacognition about reading strategies was on average. Similarly, Yemenici and Ulu (2020) collaborated with pre-service teachers who studied at elementary, Turkish language, and pre-school education departments and they reported that those teachers' metacognitive reading strategies awareness was on average, as well.

While teachers' awareness of pedagogies of metacognition might be insufficient, they may also suffer from implementing efficient pedagogies of metacognition. Extant findings repot pessimism about teachers' instructional practices for metacognition (i.e. Bolhuis \& Voeten, 2001; Curwen et al., 2010; Duffy, 1993; Fisher, 2002; Kerndl \& Aberšek, 2012; Ozturk, 2017a; Perry, Hutchinson, \& Thauberger, 2008; Thomas \& Barksdale-ladd, 2000). Such findings coming from international arena were also seconded by Turkish researchers. Ince and Duran (2013), for example, found that elementary school teachers were not able to integrate pedagogies of metacognition into their classes although they were familiar with metacognition. Most of the teachers reported that they felt incompetent with teaching strategies to monitor comprehension or to regulate strategies for it. They also reported that elementary teachers might not implement metacognitive pedagogies because of time-limitations and big number of students in a classroom. A survey research carried out by Sulak and Behriz (2018) reported similar findings. They examined 132 elementary teachers' practices of metacognitive reading strategies in their Turkish classes by implementing a scale measuring teaching metacognitive reading skills. They found that elementary teachers reported a moderate integration of metacognitive reading strategies into their classes. Moreover, similar findings were also observed with pre-service teachers. Girgin and Şahin (2020), for example, recently observed 114 pre-service elementary school teachers' practices of metacognition in Turkish language classes. They found that pre-service teachers were not able to display adequate behavior to promote metacognition, especially during and after reading sections. Those teachers might not practice metacognition because of some factors such as time-limitation, number of students in a class, time and classroom management.

Finally, another important component of instruction for metacognition pertains to materials; textbooks used to facilitate such instruction. Recently, Karadağ and Tekercioglu (2019) examined secondary level Turkish books to identify cognitive and metacognitive functions in these materials. They also studied teachers' perception of metacognition in relation to the textbooks. They found that cognitive and metacognitive functions were not presented, homogenously. Metacognitive functions, mostly, pertained to 'result-oriented assessment tools' (p. 637) which are independent of text and activities. Also, text or text-based activities did not included metacognition. In 
relation, teachers did not evaluate the text or activities for metacognition rather they adopted an intuitive teaching method.

These problems of that mainstream classroom students' and teachers' lack of awareness and/or insufficient competences with metacognition may also relate to educational policies. That is, instructional or assessment practices might not develop and identify students' metacognitive capabilities, respectively because of the curricular standards and/or objectives, in practice. Taba (1962, cited in Johnson, 1969) defined curriculum as a statement identifying the curricular elements, relations of these elements, the principles and requirements of organizations under which administrative conditions they operate. In a curriculum design, there are 'objectives, "content" (substantive, operational, and valuative), activities, needs, interests, problems, functions, and disciplines' (Johnson, 1969, p. 4). These elements might be differentially emphasized, explicit or implicit, relevant or irrelevant to the scope, balanced or unbalanced, sequenced or non-sequenced, and integrated or unintegrated. Regarding these elements' variations and their relations to the major principles and requirements of the organization, it is possible to generate numerous curriculum designs (Johnson, 1969). While Johnson (1969) argued that designing curriculum is a formidable task, he also stated that the relation between curriculum and instruction might be ignored. Indeed, curriculum design is a plan of selected and ordered (a) learning outcomes to be achieved through instruction and (b) learning experiences to be provided in an instructional situation (Johnson, 1969). Moreover, Tyler's (1949, as cited in Dillon, 2009) understanding of curriculum, indeed, emphasized the congruence of curriculum and instruction. He focused on selection and assessment of the objectives as well as selection, provision, and organization of educational experiences for effective instruction. As the pioneers highlighted long ago, curriculum is a design or plan for instruction. Therefore, I chose the national curriculum of reading to analyze the presence and weight of the metacognition for its potential influences on instructional design. It is because if curriculum standards do not facilitate students' mastery of higher-order thinking, i.e. metacognition, teachers might not implement classroom instruction promoting metacognition.

For the previous hypothesis, I will study the National Curriculum of the Turkish language (NCTL) for reading (Ministry of National Education, 2019). I will limit my analysis of the grades from 1 to 8 for the rationale explained in the following section. Thereby, I will answer the following research questions in this study;

- How is metacognition represented in NCTL's reading section, if at all?

- To what extend do the NCTL standards call for metacognition in reading classes? 


\section{Rationale for the Choice of National Curriculum, Subject, and Grade Selection}

Ministry of National Education (MoNE) in Turkey implements standardized and quality education for all parties of Turkish citizens (Orhon, 2015). Regarding that two thirds of the students in Turkey come from low socio-economic backgrounds and there are regional or district differences in reaching educational opportunities, the Turkish national curriculum (TNC) prioritizes justice and fairness for especially such students coming from low socio-economic backgrounds (Orhon, 2015). As the Turkish national curriculum aims to sustain a systematic, transparent, accountable, sustainable, and fair system of education, every Turkish child might realize his potentials via educational opportunities that the state provides and grants via the Turkish Constitution, article 42 (T.C. Anayasa, 1982). Regarding these characteristics of the Turkish National Curriculum and its potentials for classroom instruction via its vision, objectives, values, competencies, assessment and evaluation approaches, as well as its developmental foundations, I chose to study the national curriculum of Turkish language, the section of reading.

This research will identify the place of metacognition in the domain of reading. Researchers like Bransford, Brown, and Cocking (2000), Papleontiou-louca (2003), Schraw, (2001), Veenman (2016), and Zimmerman (2000) argued that metacognition is not generic; that is, metacognition's manifestations is context-dependent or domain-specific. Individuals' metacognitive knowledge and use of metacognitive strategies might be different and show distinctive characteristics in each domain. For example, individuals may know and use regulatory strategies for math; however, they may not directly transfer those to accomplish reading task demands. Also, strategies used in alignment with tasks and self-knowledge for math might be different than those for reading comprehension (Ozturk, 2017b). Therefore, regarding the crucial role of reading both in schools and out of it as well as metacognition's impacts on reading performance, the focus of the study is determined as reading (in a native language; Turkish).

This study also aims to identify the place of metacognition in elementary- and middle-schools' reading curriculum regarding the importance of early initiatives in promoting and/or fostering students' metacognitive competency. Children of 6 or 8 years may possess some adequate amount of metacognitive knowledge (Baker, 2005 as cited in Veenman, 2016) and metacognitive skills, on the other hand, get sophisticated and academically-oriented when students are formally required to utilize their metacognitive repertoire. That is, from the age of 8 , children can effectively use metacognitive strategies (Veenman, 2016). Veenman (2016) also highlighted that until the age of 14, metacognition is substantially domain-specific. Regarding theoretical foundations, the focus will, therefore, be limited to the grades of the first through eight.

\section{Theoretical Perspectives: Components of Metacognition}

Flavell (1979) describes three components of metacognition including metacognitive knowledge, metacognitive strategies, and metacognitive experiences. 
Metacognitive knowledge: Metacognitive knowledge pertains to knowledge about thinking and sensitivity to act, accordingly. This set specifically pertains to knowledge about self as a reader, strategies, text, and task demands. This set of knowledge can be categorized into three as declarative, procedural, and conditional knowledge about cognitions, strategies, text, and task variables that might influence cognitions (Pintrich, Wolters, \& Baxter, 2000).

Declarative knowledge pertains to propositional knowledge (Jacobs \& Paris, 1987). Knowledge-about-self pertains to one's awareness, beliefs, understandings, and knowing about one's very own nature and nature of others as cognitive processors (Flavell, 1979; Pintrich et al., 2000). Knowledge about the task, on the other hand, pertains to one's awareness and knowledge about task variations, demands, and their influence on cognitive performance (Flavell, 1979). Lastly, knowledge about strategies includes various procedures and strategies for cognition (Pintrich et al., 2000) and their effectiveness in achieving goals (Flavell, 1979). As this study specified reading as the domain of focus, knowledge about text might pertain to one's awareness, understandings, and knowing about elements of a text, its genre, and the mechanics of its structure.

Procedural knowledge, on the other hand, pertains to an awareness of thinking (Jacobs \& Paris, 1987) and how skills - e.g. summarizing, underlining, or making inferences- operate or used (Cross \& Paris, 1988). However, such knowledge by itself may not be sufficient for successful cognitive performances. Indeed, individuals can use strategies effectively when they possess conditional knowledge. Conditional knowledge pertains to an awareness of the conditions that impact cognitions (Jacobs \& Paris, 1987); therefore, it helps individuals know when and why to use strategies. By so, individuals can adopt or adapt the most appropriate strategies, effectively in consideration of task demands, personal goals, context, and conditions (Paris, Cross, \& Lipson, 1984). Although each category is described discreetly above, these subsets might interact and influence each other.

Description of metacognitive knowledge might seem straightforward; however, it might not be easily activated, distinguished, or recognized in practice for various reasons. As Flavell (1979) argued, this is because (a) individuals' metacognitive knowledge might be inaccurate, (b) they might fail to activate it when needed, (c) it may not influence cognitions when activated, or (d) it may not be beneficial. To examine individuals' metacognitive knowledge, it is important to create opportunities where individuals can experience and use it to meet task demands or achieve personal goals, strategically.

Metacognitive experiences: Flavell (1979) recognized the importance of metacognitive knowledge on cognitive performance and argued for its practical utilization. For this, he proposed metacognitive experiences and defined it as intellectual enterprises 
that occur in the contexts where 'highly conscious thinking' is simulated and when 'quality control' over thinking is ensured (p. 908). They may be 'items of metacognitive knowledge that have entered consciousness' (p.908). Metacognitive experiences are, indeed, regulatory and modifying mechanisms for metacognitive knowledge. In relation, metacognitive experiences can impact cognitive goals and task engagements. That is, metacognitive experiences, indeed, inform metacognitive knowledge and are informed by the same repertoire.

Flavell (1979) also recognized that metacognitive experiences are important for the activation of strategies at cognitive or metacognitive levels. Metacognitive experiences can help individuals activate metacognitive knowledge when they encounter task demands or set goals and select appropriate cognitive strategies. Individuals might also need to use metacognitive strategies to monitor their progress towards task fulfillment or goal-achievement, to evaluate the effectiveness of their strategies, or to change the strategies, if necessary. Metacognitive experiences enable personal, subjective, and tacit metacognitive knowledge (Veenman et al., 2006) via the execution of strategies.

Metacognitive regulation: Metacognitive regulation represents metacognitive knowledge in action in the case of metacognitive experiences. That is, it pertains to the regulation of cognition via planning, monitoring cognitive acts and regulating strategies, and evaluation of cognitions and performances.

Goal-setting, making predictions, allocating resources and time, selecting and sequencing appropriate strategies, and allocating attention, selectively falls under planning (Jacobs \& Paris, 1987; Schraw, 1998). While they help with monitoring in particular (Pintrich et al., 2000), these strategies are used to optimize task performance (Paris et al., 1984).

Regulation pertains to process-oriented components of metacognition (Pintrich, 2002). Individuals' engagement in monitoring and adapting strategies to meet task demands or achieve goals is known as regulation. As Pintrich and colleagues (2000) stated, it may not be easy to distinguish monitoring and regulating from each other in practice. For clarity, these metacognitive skills can be separated, conceptually as in the following. Monitoring refers to one's awareness of cognitive activities and task-performance. It is generally accompanied with metacognitive judgements that relates to (a) ease of learning, (b) judgments of learning, (c) feeling of knowing, and (d) confidence. On the other hand, regulation pertains to changing cognitions and behaviors to meet task demands or achieve goals.

For evaluations, individuals need to examine the efficacy and products of cognitive enterprises (Schraw, 1998). It both stands as goal-directed cyclical process (Jacobs \& Paris, 1987) and provides a standard to determine 'the task difficulty relative to one's abilities ... [or] relative effectiveness of different strategies' that contribute to task performance (Paris et al., 1984, p. 1241). 


\section{Metacognition in Reading}

Metacognition can be recognized via individuals' knowledge about reading and regulation of reading to meet task demands (Garner, 1981; Pressley, 2002). That is,

- metacognitive readers possess a strong sense of 'meaningfulness' of reading (Gourgey, 1998, p. 84),

- see knowledge as organized set of concepts (Long \& Long, 1987),

- understand the nature of reasoning (Duffy, 1993),

- know text features and structures (Pressley \& Afflerbach, 1995),

- know each reading task might require different approaches or strategies (Duffy et al., 1987; Gourgey, 2001; Zimmerman, 2002),

- know a variety of cognitive and metacognitive strategies (Ozturk, 2017b),

- know their own characteristics (e.g. interests, goals, and attitudes toward reading), strengths, and weaknesses as a reader (Gourgey, 1998; Pressley \& Afflerbach, 1995; Zimmerman, 2002),

- perceive compression as a satisfying and productive act (Duke \& Pearson, 2008),

- do meaning-oriented reading (Anastasiou \& Griva, 2009),

- selectively attentive to reading (Anastasiou \& Griva, 2009), and

- engage in and control thoughtful and adaptive reasoning (Duffy, 1993).

Before reading, metacognitive readers

- review task demands and set goals to read (Afflerbach \& Meuwissen, 2005; Anastasiou \& Griva, 2009; Gourgey, 2001),

- preview the text; activate prior knowledge, review content and text structure, as well as make some predictions (Anastasiou \& Griva, 2009; Michael Pressley \& Gaskins, 2006),

- determine most useful strategies and allocate resources such as time or other resources (Afflerbach \& Meuwissen, 2005; Anastasiou \& Griva, 2009; Gourgey, 2001).

During reading, metacognitive readers

- monitor comprehension; paraphrase, summarize the text, or construct images for comprehension (Ozturk, 2017b), 
- use and regulate a variety of cognitive and metacognitive strategies to meet task demands or achieve personal goals (Afflerbach \& Meuwissen, 2005; Baker \& Brown, 1984a, 1984b; Zimmerman, 2002),

- adjust rate of reading, cognitive processing, and standards of comprehension building (Jacobs \& Paris, 1987),

- apply fix-up strategies such as underlining, re-reading, reading aloud, or checking the meaning of unknown words (Ozturk, 2017b),

- reflect on the main idea or conflicting ideas (Ozturk, 2017b),

- check their predictions and inferences to make decisions (Ozturk, 2017b),

- check the alignment between text content and prior knowledge or experiences (Ozturk, 2017b),

- anticipate test questions or do self-questioning for comprehension (Ozturk, 2017b),

- generate and use their own feedback for comprehension and strategy use (Gourgey, 2001).

After reading, such readers can

- transfer skills into different task situations (Anastasiou \& Griva, 2009; Zimmerman, 2002),

- assimilate or associate new knowledge for future uses (Ozturk, 2017; Pressley \& Gaskins, 2006),

- do self-assessment for comprehension, effectiveness of the strategies, and task performance (Afflerbach \& Meuwissen, 2005; Gourgey, 1998; Palinscar \& Brown, 1984).

In the following sections, the methodoly of investigating the presence and weight of metacognition in the NCTL, reading standards, will be disseminated. Findings will reveal whether and how much the reading standards recognize and articulate metacognition, if at all.

\section{Methodology}

\section{Research Design}

I implemented a qualitative research methodoly for this study. As this study examined the national curriculum of Turkish language (NCTL), specifically reading standards, regarding metacognition, I employed a case study method. To Merriam (2002), the 'case study is an intensive description and analysis of a phenomenon... in a bounded, integrated system' (p.8). As metacognition in Turkish language curriculum and 
its representation by the standards of reading is unique, the unit of analysis characterizes a case embedded in the Turkish reading curriculum at elementary and middle school levels.

\section{Data Collection Procedures}

To identify the place and weight of metacognition in NCTL, I employed document analysis procedures. Bowen (2009) defined document analysis as a systematic procedure that is used to review or evaluate documents. As documents are 'social facts' that are produced, shared, and used in organized ways (Atkinson \& Coffey, 1997, p. 47 as cited in Bowen, 2009) without researchers' intervention, available data can be examined and interpret to develop understandings and empirical knowledge about the phenomenon (Bowen, 2009).

\section{Data Source}

The national curriculum (NC) is presented online by the Ministry of National Education. It aims to help educate individuals who can produce knowledge and use it practically, solve problems, think critically, take initiatives, show perseverance, communicate well, and contribute to the social and cultural repertoire of the country. To develop the NC, the recent advancements in science and technology, changes in social and individual needs, as well as theories and recent arguments in the field are scrutinized (Ministry of National Education, 2019).

The NL has a spiral nature. That is, while it presents various grade-level objectives, it mainly aims to help students accomplish some values, skills, and competencies across the grades, holistically. The national curriculum is a program that (a) aims to guide individuals to use metacognitive skills, (b) promotes meaningful and permanent learning, (c) provides learners with opportunities to relate previous knowledge to extant learning experiences, life, and other disciplines, as well as (d) harmonizes various values and competencies (Ministry of National Education, 2019, p.2).

This study specifically focused on the National Curriculum of Turkish Language (NCTL) to identify the place of metacognition for reading education. Developed in alignment with the NC, the NCTL specifically aims to help individuals develop socially, communicate well, as well as acquire and practice cognitive and literacy skills. NCTL recognizes that development and use of language skills and cognitive competencies is a prerequisite for learning, social development, and professional skills. It; therefore, focuses on both accomplishment of language skills; reading, listening, writing, and speaking and use of metacognitive skills (Ministry of National Education, 2019, p.8).

\section{Data Analysis Procedures}

I employed a thematic analysis to identify the place of metacognition and its weight in the NCTL. For this purpose, I utilized some elements of the curriculum design 
which Johnson (1969) emphasized. They were (a) explicitness or implicitness of metacognition and (b) balance of metacognition across the curriculum. Moreover, I deductively coded the NCTL for the components of metacognition theory at each grade, accordingly. The codes were set as (1) metacognitive knowledge, (2) metacognitive strategies, and (3) metacognitive experiences.

The document, at first, presents general information about the curriculum. In this section, explicit and/or implicit existence of metacognition in the vision, objectives, values, competencies, teaching and learning approaches, as well as assessment and evaluation approaches were analyzed. Following the initial analysis, the reading section of the NCTL was analyzed for metacognition's presence in its vision, teaching and learning approaches, and assessment and evaluation approaches. Then, at each grade level, reading standards which are comprised of mechanics of reading, vocabulary, and comprehension standards were examined for (1) metacognitive knowledge, (2) metacognitive regulation, and (3) metacognitive experiences. Finally, reading standards were studied vertically to identify the (b) balance of standards for the development of metacognition in a spiral curriculum.

\section{Reliability}

Reliability of qualitative research pertains to consistency (Leung, 2015). As Silverman (2009 as cited in Leung, 2015) proposed, reliability can be enhanced via 'reputational analysis, constant data comparison, comprehensive data use, inclusive of the deviant case and use of tables' (p. 326). Researchers can extract data from their sources and verify their accuracy with a constant comparison methodology either alone or with peers (Leung, 2015). I examined the curriculum at three different intervals. There were 3 to 4 weeks between each analysis. The internal consistency of 1st and 2nd analyses was .90. The next analysis (between 2nd and 3rd) produced an .99.

\section{Findings}

\section{Metacognition in the National Curriculum}

The Turkish national curriculum guides practitioners' instruction via its vision, objectives, values, competencies, assessment and evaluation approaches, as well as its developmental foundations. Under these subsections, metacognition or implicit manifestations of metacognition were observed.

As seen on Table 1, metacognition is either explicitly or implicitly highlighted in the curriculum. In the vision section, use of metacognitive skills is explicitly presented. Moreover, objectives, values, competencies, and developmental foundations recognized manifestations of metacognition, implicitly. Except assessment and evaluation approaches, metacognition is recognized to help learners achieve the objectives of the curriculum (i.e. self-awareness and self-discipline), develop some values (i.e. self-control and responsibility), and master some competencies (i.e. learning about learning). Moreover, developmental foundations section also recognizes that thinking affects and gets affected by language development. 
Table 1. Place of Metacognition in the National Curriculum

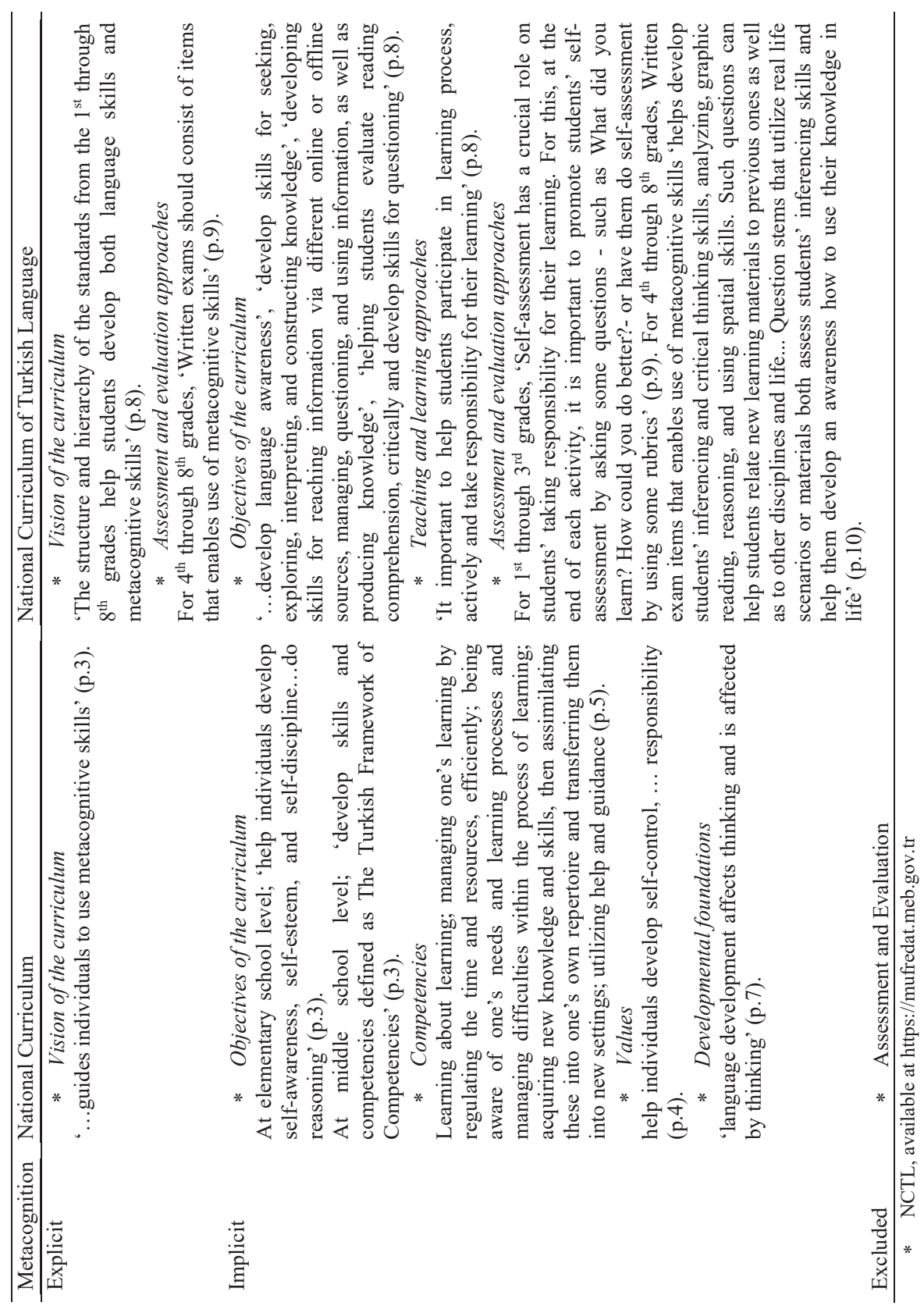




\section{Metacognition in National Curriculum of Turkish Language}

Metacognition in the NCTL is both highlighted, explicitly and indicators of metacognition can be traced, implicitly. The vision statement as well as assessment and evaluation approaches explicitly focuses on metacognition. It is stated that the curriculum aims to develop students' both language skills and metacognitive skills (Ministry of National Education, 2019, p.8). Moreover, especially from the 4th grade through 8th grade, written exams should consist of items that have students use metacognitive skills as seen on Table 1.

The NCTL also implies promotion of metacognition through its objective, teaching and learning approaches, as well as assessment and evaluation approaches. The NCTL aims to develop students' language awareness, skills for seeking, exploring, interpreting, questioning, using, and producing knowledge while evaluating comprehension, critically. To achieve these goals, practitioners are advised to manage instructional practices for students' active participation and responsibility taking for learning. Moreover, especially form the 1st grade, practitioners also suggested students' doing self-assessment during their instructional and/or for assessment practices. For this, they can ask some thought-provoking questions about extant learning experiences or use rubrics to promote self-assessment. Similarly, as students get mature, written exams may include items which require students to do inferencing, analyzing, reasoning, and use critical thinking skills as well as spatial skills. Especially via real-life scenarios or materials that are embedded in the question stems, students' awareness how to use school-knowledge in real life, that is transfer of knowledge, can be promoted (Ministry of National Education, 2019).

\section{Metacognition trough the NCTL Standards}

Reading standards in the NCTL are basically divided into three categories as mechanics, vocabulary, as well as comprehension in the document presented by MoNE (Ministry of National Education, 2019). The codes of this study were imposed on standards for their potential promotion of (1) metacognitive knowledge (MK), (2) metacognitive skills/regulation (MR), and (3) metacognitive experiences (ME) as seen on Table 2. I found that 'metacognition' is not explicitly presented in any of the standards at any grade level. However, the analyses highlighted that in general NTCL standards can promote students' declarative knowledge about the text structure, genres, and mechanics from the very early grades of elementary school and procedural knowledge about use of language mostly at middle school level. Middle school standards may also improve students' conditional knowledge of language structures. 
MİLLî EĞİTiM • Cilt: 51 • Kış/2022 • Sayı: 233, (837-861)

Table 2. Metacognition by the Reading Standards of Elementary and Middle School

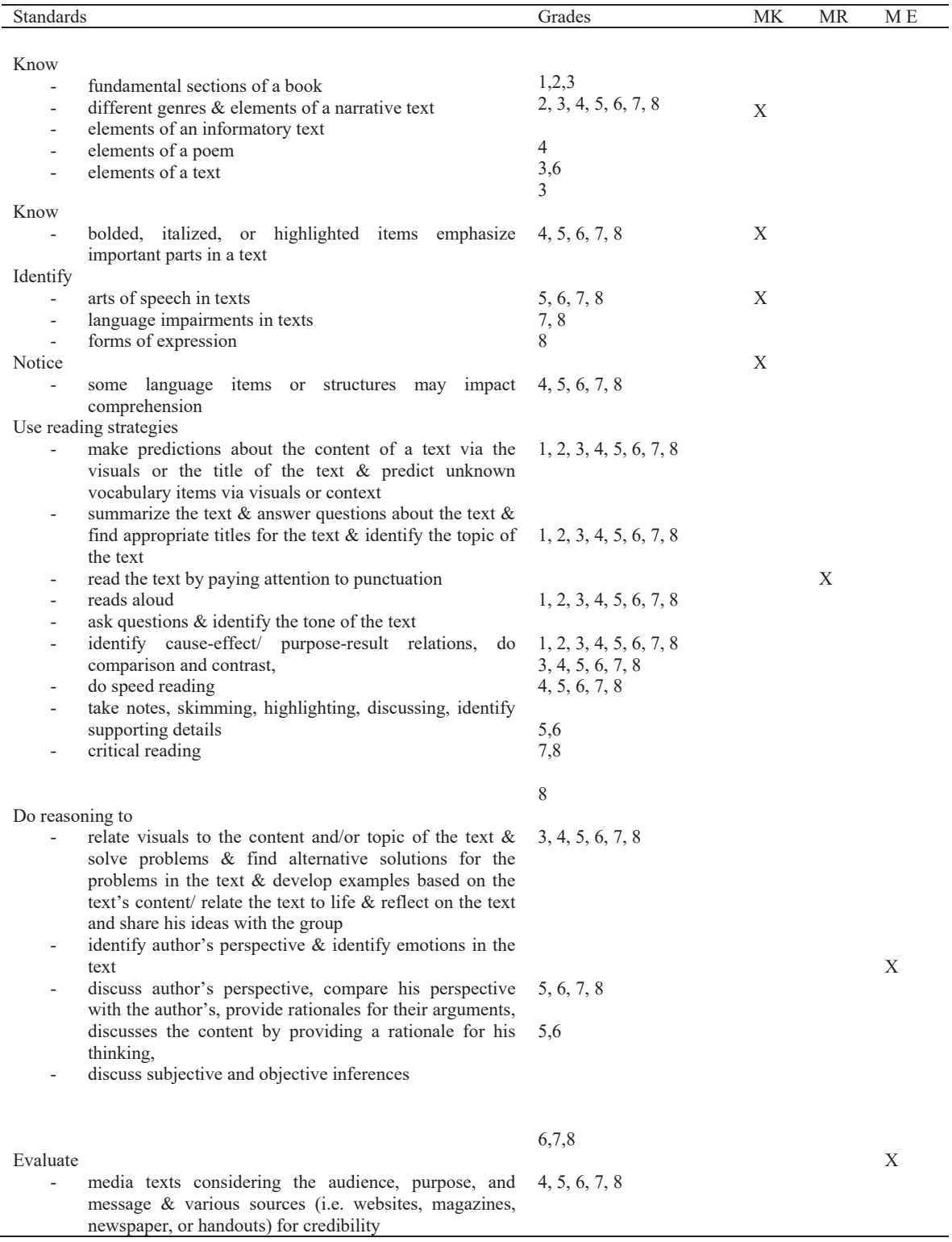


The NCTL standards, moreover, hold potentials for the development of metacognitive skills. From the first grade to the 8th grade, standards emphasize students' (a) making predictions about the content of the text via either visuals and/or the title, (b) predicting unknown vocabulary items via visuals or the content of the text (c) summarizing the text, finding appropriate titles, identifying the topic of the text, and answering questions about the text, as well as (d) reading by paying attention to punctuation marks. By the NCTL standards, students may also employ some fix-up and/ or regulatory strategies like reading aloud, asking questions, identifying various forms of arguments (i.e. cause- effect, purpose- result, comparison-contrast), and doing speed reading. At middle school level, instructional practices might include regulatory strategies such as taking notes, skimming, highlighting, discussing the content, identifying supporting details, and doing critical reading.

Finally, the NCTL standards provide opportunities for metacognitive experiences where students' highly conscious thinking and/or reasoning can be activated. Especially, starting from the later grades of elementary school and throughout middle school, standards require students to relate the visuals and topic and/or content of the text, solve problems presented in the text, find alternative solutions to those problems in the text, reflect on the text, and relate the text to the life or develop examples based on the arguments in the text. Also, at middle school level, standards require students to identify and discuss authors' perspective as well as engage in comparing different perspectives while providing rationales for arguments. Discussing text content and subjective as well as objective inferences also ensured by the NCTL standards. Finally, students may also engage in reasoning when they are asked to evaluate the text for its credibility.

\section{Weight of Metacognition through NCTL Standards}

The potential distribution of metacognitive components varies across grades. At elementary school level, standards may dominantly promote metacognitive regulation; however, metacognitive knowledge and experiences is subordinate. On the other hand, at middle school level, the uneven distribution of metacognitive knowledge and regulation is balanced. As seen on Table 1, the percentage of potential metacognitive components through standards constitute half and/or more than half of the standards across elementary and middle school grades. 
Table 3. Weight of Metacognition across Elementary and Middle School NCTL Standards

\begin{tabular}{llllll}
\hline Grades & $\begin{array}{l}\text { Number of Standards } \\
\text { by Grades }\end{array}$ & $\begin{array}{l}\text { MK } \\
\text { Standards }\end{array}$ & $\begin{array}{l}\text { MR } \\
\text { Standards }\end{array}$ & $\begin{array}{l}\text { ME } \\
\text { Standards }\end{array}$ & $\begin{array}{l}\text { Total } \\
\text { Weight }\end{array}$ \\
\hline ELEM-1 & 19 & 1 & 8 & X & $47 \%$ \\
ELEM-2 & 19 & 3 & 8 & X & $59 \%$ \\
ELEM-3 & 28 & 4 & 10 & 2 & $57 \%$ \\
ELEM-4 & 37 & 4 & 10 & 5 & $51 \%$ \\
MID-5 & 34 & 9 & 10 & 5 & $70 \%$ \\
MID-6 & 35 & 13 & 10 & 5 & $80 \%$ \\
MID-7 & 38 & 10 & 12 & 5 & $70 \%$ \\
MID-8 & 35 & 11 & 11 & 5 & $77 \%$ \\
\hline
\end{tabular}

\section{Discussion and Conclusions}

This study was developed to identify one of the potential reasons and produce solutions, if at all, for a fundamental problem in the field of teaching metacognition. Since the introduction of the theory, metacognition has been exclusively studied and various studies reported beneficiary impacts of metacognition on reading. However, this phenomenon needs a more comprehensive understanding to eliminate differences in research and mainstream classrooms that might stem from any factors including educational policies, instructional and assessment practices, teachers' competencies, and/or materials. For this, I analyzed the primary source (the national curriculum of Turkish) that shapes instruction in mainstream reading classrooms in Turkey to identify the place and weight of metacognition.

Initially analyzing the explicitness and/or implicitness of metacognition in the curriculum, I found that both NC and NCLT explicitly presents metacognition. As NC shapes domain specific curricula, its impacts are visible in the vision, teaching and learning, as well as assessment and evaluation approaches of the NCTL. The NCTL aims to develop students' language skills and metacognitive skills by students' active participation in learning process, responsibility taking, and self-assessment. Specifically, students' development of language awareness, skills for seeking, exploring, questioning, interpreting, constructing or producing knowledge, managing, questioning, and using information, evaluating reading comprehension, critically, and their doing self-assessment (Ministry of National Education, 2019, p.8) is emphasized in the NCTL.

The NCTL, however, does not define and provide specifications for metacognition and such a limitation clearly impacts the representation of metacognition trough the NCTL standards. The standards may only promote some competencies of metacogni- 
tion. Regarding metacognitive knowledge, the standards may increase students' declarative and/or procedural knowledge about text structure, genres, mechanics, and language awareness as well as use, respectively. I call these components as personally-uncontrollable facets of reading as they are independent of individuals. However, metacognition theory also emphasizes increasing students' knowledge about reading -itself-, self -as a reader-, strategies, (Gourgey, 1998; Pressley \& Afflerbach, 1995; Zimmerman, 2002) and task demands (Afflerbach \& Meuwissen, 2005; Gourgey, 2001). The current form of the NCTL standards, therefore, might ignore a very fundamental aspect of metacognition; students might not develop an understanding and ownership of reading. They may not develop an understanding what reading is, what it is for, how it happens, who they are in the face of reading, and what they can do by reading. These facets might be named as personally-controllable facets of metacognitive knowledge as such knowledge can be constructed via personal experiences and/or reasoning. Such knowledge may reflect variations as the characteristics of individuals differ. While the NCTL might develop knowledge of personally-uncontrollable facets of reading; students need to develop an awareness of personally-controllable facets to relate to and gain an ownership of reading.

The NCTL standards may also enable students to develop metacognitive skills to a limited extend. Specifically, regarding metacognitive skills for reading which include planning reading, monitoring comprehension and regulation of strategies, and evaluating task completion and/or goal-achievement process and performance, the NCTL presented a limited set of strategies and repeated those throughout elementary and middle school as seen on Table 2 . For planning reading, the standards only included making predictions about the content of the text via the visuals or title; however, this section also needs to include setting a goal for reading, identifying task demands, choosing resources for task completion, choosing and sequencing strategies for comprehension building besides making predictions about the content of the text (Anastasiou \& Griva, 2009; Gourgey, 2001; Michael Pressley \& Gaskins, 2006). Moreover, the standards included some during reading strategies such as predicting unknown vocabulary items using the context, paying attention to punctuation, reading aloud, asking questions, identifying the topic and supporting detail, identifying cause-effect and/ or purpose-result relations in the text, doing speed reading, taking notes, skimming, highlighting, and doing critical reading. Although the NCTL standards presented several strategies for especially during reading, they may stand as absolute separate skills that are practiced due to curricular mandates unless students know that these strategies can be used interchangeably and purposefully to fix comprehension breakages and to meet goals or demands (Afflerbach \& Meuwissen, 2005; Ozturk, 2017b). In addition, evaluation skills of reading presented by the NCTL standards might be limited to comprehension as they just focus on summarizing the text, answering questions about the text, and finding appropriate titles for the text. However, strategic reading pertains to evaluating reading processes, effectiveness of strategies, as well 
as successful completion of task demands and/or products for achieving goals (Afflerbach \& Meuwissen, 2005; Gourgey, 1998; Palinscar \& Brown, 1984). Finally, none of the standards either include or promote self-assessment; however, self-assessment is an indicator of autonomous learners and it, indeed, may guarantee strategic reading experiences (Afflerbach \& Meuwissen, 2005).

Reading standards in the NCTL might not sufficiently facilitate classroom instruction for teaching metacognition and may lead to similar results as already reported by previous research. When metacognitive knowledge of mechanics and limited number of metacognitive skills are presented separately and repeatedly across elementary and middle school, elementary or middle school students' metacognition might stay average as reported by Altunkaya and Sülükçü (2018), Çetinkaya Edizer and Özbilgin (2019), Öksüz et al. (2015), and Sevgi and Çağlıköse (2020). Recent initiatives of the NCTL might not change such findings unless standards initiate students' ownership of reading processes and products where they engage in personally-controllable facets of reading and unless a larger set of metacognitive strategies are presented, interchangeably across the grades.

Also, regarding teachers' low awareness (i.e. Erdağ1 Toksun \& Toprak, 2019; Yemenici \& Ulu, 2020) and insufficient practices (i.e. Girgin \& Şahin, 2020; İnce \& Duran, 2013; Sulak \& Behriz, 2018) of teaching metacognition as well as textbooks' limited presentation of metacognition (Karadağ \& Tekercioglu, 2019), the NCTL reading standards might not support teachers' practices. Even, it may produce similar findings which were reported by Girgin and Şahin (2020). The standards in its current form might lead to a lack of instructional practices regarding (a) pre-reading metacognitive strategies, (b) interchangeability and interdependence of during reading strategies, and (c) variety in after-reading strategies in reading classrooms.

Lastly, while the NCTL reading standards offer a limited space for metacognitive knowledge and metacognitive skills, its inclusion of metacognitive experiences might be supplementary. These standards that pertain to metacognitive experiences were presented in accordance with the theory of metacognition and they may promote students' engagement in higher order thinking and reasoning. Indeed, the standards require students' doing critical thinking to relate the visuals and the text, solve problems and/or find alternative solutions to the problems presented in the text, develop examples using the text content and relate the text to life, discuss and compare authors' perspective, discuss inferences, and provide rationales for their arguments. They also evaluate media texts and sources for elements of rhetorical situations and credibility, respectively. These standards might help students set the goals or help them identify task demands; therefore, they might select and regulate strategies for comprehension and task completion. That is, they may do active and reflective thinking; reasoning which is one of the fundamentals of strategic reading (Ozturk, 2017b). However, it is also possible that not all students can manage these cognitions on their own, sufficiently due to variations in their capabilities and knowledge. 


\section{Recommendations}

I identified that the NCTL recognizes metacognition and its standards reflect it, partially; the standards might promote metacognitive knowledge and skills in mainstream reading classrooms to a limited degree and in imbalanced ways. Metacognitive experiences where students may engage in higher order thinking and reasoning might substitute limited metacognitive knowledge and skills for some students. However, some other students' development cannot be jeopardized. For this reason, I suggest that the NCTL reading standards should be revised for the inclusion of;

- a definition for metacognition,

- specifications of metacognitive components,

- expansion of metacognitive knowledge to improve students' awareness about self (as a reader), reading (the nature), and tasks (functions of reading),

- explicit emphasis on conditional knowledge about reading strategies,

- expansion of strategies for planning reading; inclusion of goal setting, identifying task demands, allocation of resources, and choosing and sequencing strategies,

- inclusion of conditional knowledge about planning strategies,

- inclusion of metacognitive knowledge about comprehension monitoring and regulating strategies,

- inclusion of metacognitive knowledge about evaluating strategies,

- inclusion of evaluating self as a reader, reading process, and products; self-assessment,

- inclusion of evaluating reading materials chosen by student.

Moreover, it is important to revise teacher education programs regarding the recent research findings on teachers' awareness and practices of metacognition. There might be elective classes on metacognition where pre-service teachers learn about the theory and pedagogies of metacognition. The instructional practices of metacognition are beyond the scope of this paper; however, literature is available to facilitate teaching metacognition in mainstream classrooms. 


\section{References}

AFFLERBACH, P., \& MEUWISSEN, K. (2005). Teaching and learning self-assessment strategies in middle school. In S. E. Israel, C. Collins Block, K. L. Bauserman, \& K. Kinnucan-Welsch (Eds.), Metacognition in Literacy Learning: Theory, Assessment, Instruction, and Professional Development (pp. 141-164). Erlbaum.

ALTUNKAYA, H., \& SÜLÜKÇÜ, Y. (2018). 7. sınıf öğrerncilerinin okuma stratejileri üstbilişsel farkındalık düzeyleri ile okuduğunu anlama becerileri arasındaki ilişki. Uluslararası Türkçe Edebiyat Kültür Eğitim Dergisi, 7(4), 2502-2517.

ANASTASIOU, D., \& GRIVA, E. (2009). Awareness of reading strategy use and reading comprehension among poor and good readers. Elementary Education Online, 8(2), 283-297.

BAKER, L. (2017). The development of metacognitive knowledge and control of comprehension: Contributors and consequences. In K. Mokhtari (Ed.), Improving Reading Comprehension through Metacognitive Reading Strategies Instruction (pp. 1-31). Rowman \& Littlefield.

BAKER, L., \& BROWN, A. L. (1984a). Cognitive monitoring in reading. In J. Flood (Ed.), Understanding Reading Comprehension (pp. 21-44). International Reading Association.

BAKER, L., \& BROWN, A. L. (1984b). Metacognitive skills and reading. In P. D. Pearson, R. Barr, J. L. Kamil, \& P. Rosenthal (Eds.), Handbook of Reading Research (Vol. 1, pp. 353-394). Longman.

BOLHUIS, S., \& VOETEN, M. J. (2001). Toward self-directed learning in secondary schools: What do teachers do? Teaching and Teacher Education, 17(7), 837-855.

BOOK, C., DUFFY, G. G., ROEHLER, L. R., MELOTH, M. S., \& VAVRUS, L. G. (1985). A study of the relationship between teacher explanation and student metacognitive awareness during reading instruction. Communication Education, 34, 29-36.

BOULWARE-GOODEN, R., CARREKER, S., THORNHILL, A., \& JOSHI, R. M. (2007). Instruction of metacognitive strategies enhances reading comprehension and vocabulary achievement of third-grade students. The Reading Teacher, 61(1), 70-77.

BOWEN, G. A. (2009). Document analysis as a qualitative research method. Qualitative Research Journal, 9(2), 27-40. https:/ /doi.org/10.3316/QRJ0902027

BRANSFORD, J., BROWN, A. L., \& COCKING, R. R. (2000). How People Learn: Brain, Mind, Experience, and School (Expanded). National Academy.

CARROLL, M. (2008). Metacognition in the classroom. In J. Dunlosky \& R. A. Bjork (Eds.), Handbook of Metamemory and Memory (pp. 411-427). Psychology Press.

ÇETINKAYA EDIZER, Z., \& ÖZBILGIN, E. (2019). Sekizinci sınıf öğrencilerinin üstbilişsel okuma farkındalıkları. OPUS Uluslararası Toplum Araştırmaları Dergisi, 10(17), 154-175. https://doi.org/10.26466/opus.501825

CROSS, D. R., \& PARIS, S. G. (1988). Developmental and instructional analyses of children's metacognition and reading comprehension. Journal of Educational Psychology, 80(2), 131-142. https://doi.org/10.1037/0022-0663.80.2.131 
CURWEN, M. S., MILLER, R. G., WHITE-SMITH, K. A., \& CALFEE, R. C. (2010). Increasing teachers' metacognition develops students' higher learning during content area literacy instruction: Findings from the read-write cycle project. Issues in Teacher Education, 19(2), 127-151.

DILLON, J. T. (2009). The questions of curriculum. Journal of Curriculum Studies, 41(3), $343-$ 359. https://doi.org/10.1080/00220270802433261

DOĞANAY BILGI, A., \& ÖZMEN, E. R. (2014). The impact of modified multi-component cognitive strategy instruction in the acquisition of metacognitive strategy knowledge in the text comprehension process of students with mental retardation. Educational Sciences: Theory \& Practice, 14(2), 707-714.

DUFFY, G. G. (1993). Rethinking strategy instruction: Four teachers' development and low achievers' understandings. Elementary School Journal, 93(3), 231.

DUFFY, G. G., ROEHLER, L. R., SIVAN, E., RACKLIFFE, G., BOOK, C., MELOTH, M. S., VAVRUS, L. G., WESSELMAN, R., PUTMAN, J., \& BASSIRI, D. (1987). Effects of explaining the reasoning associated with using reading strategies. Reading Research Quarterly, 22(3), 347-368.

DUKE, N. K., \& PEARSON, P. D. (2008). Effective practices of developing reading comprehension. Theory, Research, Reflection on Teaching and Learning, 189(1/2), 107-122.

ERDAĞI TOKSUN, S., \& TOPRAK, F. (2019). Türkçe öğretmenlerinin okuma stratejileri bilişsel farkındalık becerilerini kullanma düzeylerine ilişkin bir araştırma (Kars ili örneği). Uluslararası Türkçe Edebiyat Kültür Eğitim Dergisir, 8(2), 1137-1157.

FISHER, R. (2002). Shared thinking: Metacognitive modelling in the literacy hour. Reading, 36(2), 63-67.

FLAVELL, J. H. (1979). Metacognition and cognitive monitoring: A new area of cognitive-developmental inquiry. American Psychologist, 34(10), 906-911.

GARNER, R. (1981). Monitoring of passage inconsistency among poor comprehenders: A preliminary test of the "piecemeal processing" explanation. The Journal of Educational Research, 74(3), 159-162.

GİRGIN, D., \& ŞAHIN, Ç. (2020). Sınıf öğretmeni adaylarının üstbilişsel okuma stratejilerini kullandırma düzeyleri : Bir karma yöntem çalışması. Ana Dili Eğitimi Dergisi, 8(4), $1149-1173$.

GOURGEY, A. F. (1998). Metacognition in basic skills instruction. Instructional Science, 26, 81-96.

GOURGEY, A. F. (2001). Metacognition in basic skills instruction. In H. J. Hartman (Ed.), Metacognition in Learning And Instruction: Theory, Research, and Practice (pp. 17-32). Kluwer.

INCE, Y., \& DURAN, E. (2013). Sınıf öğretmenlerinin okuduğunu anlama stratejilerine yönelik görüşlerinin ve bu stratejileri kullanma düzeylerinin incelenmesi. Okuma Yazma Eğitimi Araştırmaları, 1(1), 9-19.

JACOBS, J. E., \& PARIS, S. G. (1987). Children's metacognition about reading: Issues in definition, measurement, and instruction. Educational Psychologist, 22(3), 255-278. 
JOHNSON, M. (1969). On the meaning of curriculum design. Curriculum Theory Network, Spring(3), 3-9.

KARADAĞ, Ö., \& TEKERCIOGLU, H. (2019). Türkçe ders kitaplarındaki bilişsel ve üstbilişsel işlevlere dair bir durum tespiti. Mersin Üniversitesi Eğitim Fakültesi Dergisi, 15(3), 628-646. https://doi.org/10.17860/mersinefd.594240

KERNDL \& ABERŠEK, M. K. (2012). Teachers' competence for developing reader's reception metacognition. Problems of Education in the 21st Century, 46(1979), 52-61.

LEUNG, L. (2015). Validity, reliability, and generalizability in qualitative research. Journal of Family Medicine and Primary Care, 4(3), 324-327.

LONG, J. D., \& LONG, E. W. (1987). Enhancing student achievement through metacomprehension training. Journal of Developmental Education, 11(1), 2-5.

MERRIAM, S. B. (2002). Introduction to qualitative research. In S. B. M. \& Associates (Ed.), Qualitative Research in Practice: Examples for Discussion and Analysis (pp. 1-17). Jossey-Bass.

MINISTRY OF NATIONAL EDUCATION. (2019). Curriculum of Turkish Language. http:/ / mufredat.meb.gov.tr/ProgramDetay.aspx?PID=663

MYERS, M., \& PARIS, S. G. (1978). Children's metacognitive knowledge about reading. Journal of Educational Psychology, 70(5), 680-690.

ÖKSÜZ, M., \& SEÇKIN KAPUCU, R. (2015). Ortaokul öğrencilerinin üstbilişsel farkındalıklarının incelenmesi. Eğitim Ve İnsani Bilimler Dergisi: Teori Ve Uygulama, 6, 5-28.

ORHON, N. (2015, December 12). Ulusal Eğitim Programı Nedir? https://turk-internet.com/ulusal-egitim-programi-nedir/

OZTURK, N. (2015). A short review of research on metacognition training. Journal of Educational and Instructional Studies in the World, 5 (3), 50-62.

OZTURK, N. (2017A). An analysis of teachers' self-reported competencies for teaching metacognition. Educational Studies, 43(3), 247-264.

OZTURK, N. (2017b). Identifying the Nature of Metacognition Instruction in Reading Classrooms (Unpublished doctoral dissertation). University of Maryland, College Park, Maryland.

PALINSCAR, A. S., \& BROWN, A. L. (1984). Reciprocal teaching of comprehension-fostering and comprehension-monitoring activities. Cognition and Instruction, 1(2), 117-175.

PAPLEONTIOU-LOUCA, E. (2003). The concept and instruction of metacognition. Teacher Development, 7(1), 9-30. https://doi.org/10.1080/13664530300200184

PARIS, S. G., CROSS, D. R., \& LIPSON, M. Y. (1984). Informed strategies for learning: A program to improve children's reading awareness and comprehension. Journal of Educational Psychology, 76(6), 1239-1252.

PARIS, SCOTT G, \& JACOBS, J. E. (1984). The benefits of informed instruction for children's reading awareness and comprehension skills. Child Development, 55(6), 2083-2093. 
PERRY, N. E., HUTCHINSON, L., \& THAUBERGER, C. (2008). Talking about teaching self-regulated learning: Scaffolding student teachers' development and use of practices that promote self-regulated learning. International Journal of Educational Research, 47, 97-108.

PINTRICH, P. R., WOLTERS, C. A., \& BAXTER, G. P. (2000). Assessing metacognition and self-regulated learning. In Gregory Schraw \& J. C. Impara (Eds.), Assessing Metacognition and Self-Regulated Learning (pp. 43-97). Buros Institute of Mental Measurements.

PINTRICH, P. R. (2002). The role of metacognitive knowledge in learning, teaching, and assessing. Theory Into Practice, 41(4), 219-225.

POGROW, S. (2004). The missing element in reducing the learning gap: Eliminating the "blank stare." Teachers College Record, 106(10), 11381.

PRESSLEY, M. (2002). Metacognition and self-regulated comprehension. In A. Farstrup \& S. J. Samuels (Eds.), What Research Has To Say About Reading Instruction (3rd ed., pp. 291-309). International Reading Association.

PRESSLEY, M., \& AFFLERBACH, P. (1995). Verbal Protocols of Reading: The Nature of Constructively Responsive Reading. Routledge.

PRESSLEY, M., \& GASKINS, I. W. (2006). Metacognitively competent reading comprehension is constructively responsive reading: How can such reading be developed in students? Metacognition Learning, 1, 99-113.

SCHRAW, G. (2001). Promoting general metacognitive awareness. In H. J. Hartman (Ed.), Metacognition in Learning and Instruction: Theory, Research, and Practice (pp. 3-16). Kluwer.

SCHRAW, GREGORY. (1998). Promoting general metacognitive awareness. Instructional Science, 26(1), 113-125.

SEVGI, S., \& ÇAĞLIKÖSE, M. (2020). Altıncı sınıf öğrencilerinin üstbiliş becerilerinin bazı değişkenler açısından incelenmesi. Cumhuriyet Uluslararası Eğitim Dergisi, 9(1), 139-157.

SULAK, S. E., \& BEHRIZ, A. (2018). Sınıf öğretmenlerinin Türkçe derslerinde öğrencilerin üstbilişsel okuma stratejilerini kullandırma düzeylerinin incelenmesi. Ordu Üniversitesi Sosyal Bilimler Araştırma Dergisi, 8(2), 393-407.

T.C. ANAYASA, Pub. L. No. 42 (1982). https://www.tbmm.gov.tr/develop/owa/tc_anayasasi. maddeler?p3=42\#: :text=42.,Madde\&text=Kimse\%2C eğitim ve öğrenim hakkından yoksun birakılamaz.\&text=Eğitim ve öğretim\%2C Atatürk ilkeleri,gözetim ve denetimi altında yapilır.

TANNER, K. D. (2012). Promoting student metacognition. Cell Biology Education, 11(2), 113-120.

THOMAS, K. F., \& BARKSDALE-LADD, M. A. (2000). Metacognitive processes: Teaching strategies in literacy education courses. Reading Psychology, 21, 67-84.

VAN KEER, H., \& VANDERLINDE, R. (2010). The impact of cross-age peer tutoring on third and sixth graders' reading strategy awareness, reading strategy use, and reading comprehension. Middle Grades Research Journal, 5(1), 33-45. 


\section{MİLLî EĞİTiM • Cilt: 51 • Kış/2022 • Sayı: 233, (837-861)}

VEENMAN, M. V. J. (2016). Metacognition. In P. Afflerbach (Ed.), Handbook of Individual Differences in Reading (pp. 26-40). Routledge.

VEENMAN, M. V. J., VAN HOUT-WOLTERS, B. H. A. M., \& AFFLERBACH, P. (2006). Metacognition and learning: Conceptual and methodological considerations. Metacognition and Learning, 1(1), 3-14. https:/ / doi.org/10.1007/s11409-006-6893-0

WANG, M. C., HAERTEL, G. D., \& WALBERG, H. J. (1990). What influences learning? A content analysis of review literature. The Journal of Educational Research, 84(1), 30-43.

YEMENICI, A. I., \& ULU, H. (2020). Öğretmen adaylarının okuma stratejileri bilişsel farkındalık düzeylerinin incelenmesi. Ana Dili Eğitimi Dergisi, 8(4), 1405-1420.

ZIMMERMAN, B. J. (2000). Attaining self-regulation: A social cognitive perspective. In M. Boekaerts, P. R. Pintrich, \& M. Zeidner (Eds.), Handbook of Self-Regulation (pp. 13-39). Academic.

ZIMMERMAN, B. J. (2002). Becoming a self-regulated learner: An Overview. Theory Into Practice, 41(2), 64-70. https:/ /doi.org/10.1207/s15430421tip4102

ZOHAR, A., \& BEN DAVID, A. (2009). Paving a clear path in a thick forest: A conceptual analysis of a metacognitive component. Metacognition and Learning, 4(3), 177-195. 